\title{
KENDALA MEDIASI PERCERAIAN PADA MAHKAMAH SYARIAH DI PANTAI BARAT SELATAN ACEH TAHUN 2016 - 2017
}

\author{
Amrizal Hamsa \\ Dosen Hukum Ekonomi Syariah, STAIN Teungku Dirundeng Meulaboh. \\ Amrizal_hamsa@gmail.com
}

\begin{abstract}
Abstrak
Artikel ini bertujuan menganalisa kendala mediasi terhadap perceraian di beberapa kabupaten yang ada di Aceh. Mediasi merupakan bentuk arternatif penyelesaian sebuah perkara yang sedang berkembang dalam masyarakat. Mediasi dianggap sebagai sebuah intrumen yang tepat dan efektif dalam menyelesaikan sebuah perkara perceraian yang terjadi pada Mahkamah Syariah. Objek penelitian pada artikel ini ialah beberapa mahkamah syariah kabupaten yang ada di barat selatan Aceh. teknik pengumpulan data dilakukan dengan melakukan deep interview dengan 32 responden dan mengumpulkan data sekunder berupa dokumen yang terkait dengan penelitian. sedangkan analisa data dalam artikel ini menggunakan analisa deskriptif dengan menjabarkan temuan-temuan yang terjadi di lapangan. Hasil yang peroleh ialah Kendala mediasi yang terjadi pada Mahkamah Syariah adalah disebabkan jarak tempuh para pihak yang berperkara, hakim terlalu muda, memahami dengan bahasa daerah, pengaruh pihakketiga, skiil mediator yang terbatas, tidak ada ruang khusus mediasi, banyaknya perkara yang harus ditangani, kurangnya pemahaman para pihak yang berperkara tentang mediasi, waktu mediasi yang terbatas dan terpaksa mengikuti mediasi secara prosedural.
\end{abstract}

Kata kunci: Mediasi, Perceraian, Mahkamah Syariah.

\begin{abstract}
This article aims to analyze the mediation barriers to divorce in several districts in Aceh. Mediation is an arternative form of solving a case that is developing in society. Mediation is considered as an appropriate and effective instrument in resolving a divorce case that occurs at the Sharia Court. The object of research in this article is a number of district sharia courts in the south west of Aceh. Data collection techniques were carried out by conducting deep interviews with 32 respondents and collecting secondary data in the form of documents related to the research. Meanwhile, the data analysis in this article uses descriptive analysis by describing the findings that occurred in the field. The results obtained are that the mediation constraints that occur at the Sharia Court are due to the distance traveled by the litigants, the judges are too young, understand the local language, the influence of third parties, limited mediator skills, no special room for mediation, the number of cases to be handled, the lack of understanding of the parties in a case about mediation, the limited time for mediation and being forced to follow procedural mediation.
\end{abstract}

Keywords: Mediation, Divorce, Sharia Court.

\section{A. PENDAHULUAN}

Perkawinan adalah sebuah peristiwa dalam kehidupan setiap manusia yang akan AT-TASYRI', Vol. 12, No. 2, Desember 2020 menimbulkan akibat lahir dan batin antara mereka berdua, pembinaan terhadap perkawinan merupakan konsekwensi logis 
dan sekaligus merupakan cita-cita sebuah keluarga. Dalam Undang-Undang Perkawinan Nomor 1 Tahun 1974 menyebutkan, bahwa tujuan dari perkawinan adalah untuk membentuk sebuah keluarga yang harmonis, bahagia, dan tidak bercerai berai, sehingga sebelum keduanya melangsungkan menikah ada perbedaan latar belakang dan pendapat yang harus mereka satukan, untuk membangun sebuah perkawinan Undang-Undang ini menganut prinsip untuk mempersulit terjadinya sebuah perceraian. Perkawinan berisi kasih sayang, saling memberi dan menerima, saling mencurahkan kasih sayang, untuk saling melindungi dan saling isi mengisi guna mencapai kedamaian, ketentraman dan kebahagiaan. ${ }^{1}$

Akhir-akhir ini angka perceraian di kalangan masyarakat sangat siqnifikan terjadi, hal ini tentu tidak terlepas dari dangkalnya pengetahuan suami istri tentang tujuan dan substansi sebuah pernikahan. Tingginya angka perceraian secara tidak langsung akan membawa efek bagi masyarakat secara luas, karena perceraian merupakan indikator gagalnya menuju sebuah keluarga sakinah, mawaddah, warahmah. Menurut fiqh perceraian dikenal dengan kata fasakh dan talak. Definisi talak menurut bahasa adalah melepaskan ikatan dan membebaskan, sedangkan menurut istilah, talak berarti melapaskan sebuah ikatan pernikahan. ${ }^{2}$ Hasil wawancara penulis dengn Hakim Mediator Mahkamah Syariah Hasanuddin menyatakan bahwa perceraian yang tiap tahun terjadi di Mahkamah Syariah sangat meningkat, sedangkan proses mediasi yang berhasil dilakukan oleh Mahkamah Syariah sangat sedikit. Maka untuk

${ }^{1}$ Alyasa' Abu Bakar, Antara Setia dan Durhaka Ulasan Tentang Hak dan Kewajiban Suami Istri, Banda Aceh: Badan Pemberdayaan Perempuan dan Perlindungan Anak Provinsi Nanggroe Aceh Darussalam, 2001, hal. 10

${ }^{2}$ Imam Taqiyuddin Abubakar bin Muhammad Alhusaini, kifayatul Akhyar, (Surabaya: bina Iman, t.t.), hal. 175 . mengurangi angka perceraian diperlukan fasilitasi dalam perkara perceraian karena fasilitasi adalah sebuah keterampilan proses penyelesaian sengketa, dimana pihak fasilitator berusaha melakukan komunikasi dengan pihak yang bersengketa yang berbeda pendapat dan pandangan dalam membangun dialog untuk menjembatani perbedaan mereka. $^{3}$

\section{B. Tinjauan Tentang Perceraian}

Perceraian asal dari kata cerai, yang berarti putus hubungan, pisah sebagai suami istri dan talak, sedangkan makna kata talak sama dengan cerai, kata menalak berarti menceraikan. Sedangkan menurut ensiklopedi nasional Indonesia, perceraian merupakan sebuah peristiwa putusnya hubungan suami isteri yang diatur menurut tata cara yang dilembagakan untuk mengatur hal itu. Dengan pengertian ini berarti kata talak sama artinya dengan cerai atau menceraikan, istilah kata talak dan cerai dalam bahasa Indonesia sudah umum dipakai oleh masyarakat dengan arti yang sama. ${ }^{4}$ Adapun menurut Abdul Rahman Ghozali talak asal dari kata ithlaq, yang artinya melepaskan, atau meninggalkan. Menurut istilah syara', talak yaitu Melepas tali perkawinan dan mengakhiri hubungan suami istri. ${ }^{5}$ Adapun menurut Abu Zakariya AlAnshari, talak ialah Melepas tali akad nikah dengan kata talak dan yang semacamnya. ${ }^{6}$ Dalan Undang-Undang Perkawinan Nomor 1 Tahun 1974 Pasal 38, disebutkan:

${ }^{3}$ Syahrizal Abbas, Mediasi Dalam Perspektif Hukum Syariah, Hukum Adat dan Hukum Nasional, (Jakarta: Kencana Prenada Media Group), hal. 12

${ }^{4}$ Adibul Farah, Kawin Paksa Sebagai Alasan Perceraian (Studi Atas Putusan Pengadilan Agama Kendal No. 0044/Pdt. G/ 2006/ PA. Kdl), Semarang: IAIN Walisongo, 2008, hal. 35

5 Abdul Rahman Ghozali, Fiqh Munakahat, Cet. Ke-3, (Jakarta Kencana, 2008), hal. 192

${ }^{6}$ Abi Yahya Zakariya al-Anshori, Fath alWahhab, Juz II (Semarang: Toha Putra,), hal. 72 
Perkawinan dapat putus karena, kematian, perceraian, dan atas keputusan Pengadilan. ${ }^{7}$

\section{Kajian Pustaka}

PERMA Nomor 1 tahun 2016 dalam pasal 1 ayat 1 menyebutkan tentang bagaimana prosedur mediasi di Pengadilan bahwa mediasi adalah cara penyelesaian sebuah sengketa melalui proses perundingan untuk memeproleh kesepakatan para pihak yang dibantu oleh mediator. ${ }^{8}$ Kesepakatan damai dari proses mediasi akan dikukuhkan menjadi akta perdamaian yang mengandung kekuatan excutorial kracht sebagaimana putusan hakim yang telah berkekuatan hukum tetap. Ketentuan dimaksudkan dari hasil kesepakatan yang telah dibuat oleh para pihak memiliki kekuatan hukum yang mengikat dan bersifat menyelesaiakan sengketa secara tuntas. ${ }^{9}$ Mediasi merupakan salah satu bentuk sebuah penyelesaian sengketa alternatif yang bersifat consensus. Sedangkan secara bahasa mediasi yang berarti ditengah "berada ditengah" ${ }^{10}$ karena mediator yang melakukan mediasi harus berada ditengah atau menengahi orang yang bertikai. Dari segi istilah banyak terdapat pendapat tentang pengertian mediasi, diantaranya mediasi adalah: Mediasi adalah sebuah proses negosiasi penyelesaian sengketa atau pemecahan masalah dimana pihak-pihak ketiga yang tidak imparsial bekerja sama dengan para pihak yang bersengketa membantu memperoleh sebuah kesepakatan perjanjian yang memuaskan. ${ }^{11}$

7 R. Subekti dan R. Tjitrosudibjo, Kitab Undang-Undang Hukum Perdata, Cet. Ke-34, (Jakarta: PT. Pradnya Paramita, 2004), hal. 549

${ }^{8}$ PERMA No. 1 tahun 2016

9 D.Y.Witanto, Hukum Acara Mediasi, (Bandung: Alfabeta, 2012), hal. 17.

${ }^{10}$ Syahrizal Abbas, Mediasi dalam Prespektif Hukum Syari'ah, Hukum Adat dan Hukum Nasional (Jakarta: Kencana, 2009), hal. 2

11 Susanti dan Adi Nugroho, Proses Penyelesaian Sengketa Konsumen. Ditinjau Dari
Dalam literature lain mediasi merupakan suatu proses dimana para pihak dengan bantuan beberapa orang, secara sistematis menyelesaikan sebuah permasalahan yang disengketakan untuk mencari alternatif sehingga tercapainya penyelesaian yang dapat mengakomodasi kebutuhan mereka. ${ }^{12}$

\section{Metodologi Penelitian}

Objek kajian penelitian ini beberapa kabutapen di Barat selatan aceh. dengan sampel Kabupaten Aceh Barat, Nagan Raya, dan Aceh Jaya. Sumber data dari penelitian ini di peroleh dengan menggunakan wawancara langsung dengan beberapa resopenden di mahkamah Syariah, seperti hakim mediator dan para pihak. data diperoleh dalam waktu 1 tahun selama tahun 2016-2017. Teknik analisa data pada penelitian ini menggunakan Analisa deskriptif, dengan menjabarkan beberapa jawaban dari rumusan masalah terkain kendala mediasi kasus percerain di mahkamah Syariah.

\section{E. Hasil dan Pembahasan}

Mahkamah Syari'ah di Pantai Barat Selatan Aceh merupakan peradilan khusus berdasarkan Qanun Syari'at Islam Provinsi Aceh. Mahkamah Syari'ah Provinsi Aceh terdiri dari Mahkamah Syari'ah Provinsi dan Mahkamah Syari'ah kabupaten dan kota. Mahkamah Syari'ah di Provinsi Aceh memiliki kewenangan absolut yaitu kewengan badan peradilan dalam memeriksa jenis perkara tertentu yang mutlak dan tidak dapat diperiksa oleh pengadilan lain. Oleh karena itu, sudah pasti kekuasaan dan kewenagan yang dimiliki Mahkamah Syari'ah lebih luas dari kekuasaan yang dimiliki Peradilan Agama. Dalam Undang-

Hukum Acara serta Kendala Implementasinya, (Jakarta: Kencana Prenada Media Group, 2008), hal. 109.

12 Rachamd Syafa'at, Avokasi dan Pilihan penyelesaian Sengketa, Latar Belakang, Konsep dan Implementaasinya, (Malang: Yayasan Pembangunan Nasional (YPN), 2006), hal. 35-36 
Undang No. 3 Tahun 2006 Tentang Perubahan atas UU No. 7 Tahun 1989 tentang Pengadilan Agama ditegaskan bahwa tugas dan wewenang Peradilan Agama adalah memeriksa, memutus, dan menyelesaikan ditingkat pertama antara orang-orang yang beragama Islam di bidang: Perkawinan, Waris, Wasiat, Hibah, Wakaf, Infaq, Sedekah dan Ekonomi Syariah. Keputusan Presiden Republik Indonesia Nomor 11 Tahun 2003 tentang Mahkamah Syari'ah kabupaten dan Mahkamah Syari'ah di Propinsi Nanggroe Aceh Darussalam menetapkan bahwa peradilan syari'ah di NAD akan dijalankan oleh sebuah lembaga dalam hal ini Mahkamah Syari'ah. ${ }^{13}$ Pada Pasal 3 ayat (1) UU No 11 Tahun 2003 menyebutkan: "Kekuasaan dan kewenangan Mahkamah Syar'iyah dan Mahkamah Syar'iyah Propinsi adalah kekuasaan dan kewenangan Pengadilan Agama dan pengadilan Tinggi Agama, ditambah dengan kekuasaan dan kewenangan lain yang berkaitan dengan kehidupan masyarakat dalam ibadah dan syiar Islam yang ditetapkan dalam qanun".

\section{Pelaksanaan Mediasi pada Mahkamah Syariah di Pantai Barat Selatan Provins Aceh}

Mediasi pada umunya dilakukan melalui suatu proses secara sukarela, atau mungkin didasarkan pada perjanjian atau pelaksanaan kewajiban (peraturan) atau perintah Pengadilan. ${ }^{14}$ Berkenaan dengan proses mediasi di Pengadilan, ketentuan dalam Pasal 2 ayat (2) PERMA No. 1 Tahun 2008 menentukan, bahwa "setiap hakim, mediator dan para pihak wajib mengikuti prosedur penyelesaian sengketa melalui mediasi yang diatur dalam peraturan ini." Jadi, proses mediasi yang dilakukan di

13 Ainal Hadi, Hukum dan Fenomena Sosial, (Bnda Aceh: Aceh Justice Resource Centre, 1997), hal. 128.

${ }^{14}$ Gatot Soemartono, Arbitrase dan Mediasi di Indonesia, (Jakarta: Gramedia Pustaka Utama, 2006), hal. 141 .
Pengadilan harus tunduk dan mengikuti aturan-aturan yang terdapat dalam PERMA No. 1 Tahun 2008. ${ }^{15}$ Sedangkan proses mediasi yang dilakukan di luar Pengadilan tidak wajib atau harus tunduk mengikuti prosedur penyelesaian sengketa melalui mediasi yang telah diatur dalam PERMA No. 1 Tahun 2008 terkecuali hal-hal yang telah diatur dalam PERMA No. 1 Tahun 2008, misalnya ketentuan dalam Pasal 2 ayat (1) PERMA No. 1 Tahun 2008 menegaskan, bahwa "Peraturan Mahakamh Agung ini hanya berlaku untuk mediasi yang terkait dengan proses berperkara di Pengadilan." Jadi aturan-aturan yang tercantum dalam PERMA No. 1 Tahun 2008 hanya untuk mediasi yang terkait dengan proses berperkara di Pengadilan pada semua tingkat Pengadilan dalam lingkungan Peradilan Umum dan Peradilan Agama. Prosedur mediasi yang diatur dalam PERMA No. 1 Tahun 2008hanya berlaku untuk mediasi di Pengadilan saja. ${ }^{16}$ Berhasil atau tidaknya mediasi tergantung dari proses yang dijalankan. Bila proses baik, tercapailah kesepakatan damai antara kedua belah pihak. Namun sebaliknya, proses yang tidak baik akan menjadikan mediasi gagal. Lembaga mediasi sebagai suatu proses yang tumbuh dan berkembang dari dan karena kebutuhan praktek penyelesaian sengketa baik antar negara, kelompok, maupun antar individu, merupakan faktor utama yang menjadikan mediasi bersifat fleksibel dan mempunyai proses atau mekanisme atau tahapan yang berbeda-beda satu sama lain yang selalu disesuaikan dengan kebutuhan dan kondisi para pihak yang bersengketa. ${ }^{17}$ Oleh karena

15 Rachmadi Usman, Mediasi di Pengadilan Dalam Teori dan Praktik, (Jakarta: Sinar Grafika, 2012), hal. 105.

${ }^{16}$ Rachmadi Usman, Mediasi di Pengadilan Dalam Teori dan Praktik, (Jakarta: Sinar Grafika, 2012), hal. 106.

${ }^{17}$ Bagir Manan, Sambutan dalam pembukaan Lokakarya yang diselenggarakan Pusat Pengkajian Hukum bekerjasama dengan Mahkamah Agung tgl 8 
itu, dalam penggunaan mekanisme atau tahapan proses mediasi, belum terdapat keseragaman dan pedoman yang baku di antara para praktisi mediasi. Pada umumnya, dalam praktek penggunaan mediasi, mekanisme atau tahapan proses mediasi dibuat berdasarkan pengalaman mereka menjadi mediator. ${ }^{18}$

\section{Kendala Hakim dalam mediasi perceraian pada Mahkamah Syariah di Pantai Barat Selatan Aceh}

Dalam pelaksanaan penyelesaian sengketa perceraian di Mahkamah Syar'iyah Pantai Barat Selatan Aceh belum bisa terlaksana dengan baik terutama dalam mediasi perkara perceraian, karena ada beberapa faktor penyebab ketidakberhasilan antara lain:

Bapak Hasanuddin mengatakan bahwa hakim mediator terlalu susah berbicara dalam memahami sebuah penyelesaian perkara perceraian artinya hakim ini pintar dalam sebuah konsep atau teori tetapi susah dalam berbicara untuk memahami para pihak yang berperkara. ${ }^{19}$

Bapak Achmad Fikri Oslami mengatakan banyaknya perkara perceraian di Mahkamah Syar'iyah Meulaboh dari tahun 2016 sampai dengan 2017 semakin meningkat, sedangkan jumlah hakim mediator sangat kurang tidak adanya hakim mediator dari luar, sehingga menambah pekerjaan para hakim di Mahkamah Syar'iyah.

Hakim Mediator Mengatakan lama waktu proses mediasi yaitu 40 hari dan 14 hari apabila mediasi gagal, ini tidak cocok bagi para pihak yang memang mereka bersikukuh untuk bercerai ini menjadi hambatan dalam proses mediasi di

dan 9 Oktober 2002 di Jakarta, tentang Arbitrase dan Mediasi, hal. 8

${ }^{18}$ Nurwidiatmo, Akibat Hukum Penggunaan Lembaga Mediasi sebagai Alternatif Penyelesaian Sengketa di Indonesia, Suatu Analisis Normatif Legalitas, Jurnal Penelitian Hukum Vol. IV No. 2 Juli -Desember 2003; hal. 166-218.

19 Wawancara Hakim Mediator Mahkamah Syar'iyah Meulaboh Tanggal 14 Oktober 2018.
Mahkamah Syar'iyah dan jarak tempuh bagi hakim dan para pihak yang berperkara dimana seorang hakim perlu kewenangan dalam menyelesaikan sebuah perkera perceraian tetapi disebabkan terlalu jauh tempat tinggal para hakim juga menjadi hambatan dalam proses mediasi. ${ }^{20}$

Bapak Hasanuddin mengatakan kurang mengertinya pihak yang berperkara tentang proses mediasi. Bagi para pihak berperkara mediasi merupakan sebuah penyelesaikan masalah, yang penting dalam prosesnya terdapat musyawarah, tidak peduli apakah dalam pembicaraan itu berat sebelah atau tidak. Para pihak yang berperkara mengikuti proses mediasi bukan karena keinginan hati, bukan karena ada peluang yang baik dari mediasi atau mereka melihat keuntungan dari mediasi. Tetapi khawatir putusan mereka akan batal demi hukum apabila tidak mengikuti proses mediasi sebelumnya artinya para pihak yang bercerai mengikuti proses mediasi karena terpaksa apabila tidak mengikuti proses mediasi maka sidang tidak bisa di daftarkan. Maka untuk itu, perlunya sosialisasi Perma Nomor 1 Tahun 2008 kepada masyarakat supaya para pihak yang berperkara nanti ke Mahkamah Syar'iyah Meulaboh sudah paham dan mengerti tentang apa dan mamfaat dari mediasi tersebut. ${ }^{21}$

Secara umum hambatan-hambatan proses mediasi pada Mahkamah Syar'iyah antara lain; jarak tempuh hakim dan juga para pihak yang berperkara ke Mahkamah Syar'iyah, usia sebagian hakim yang masih muda menyebabkan komunikasi dengan pihak berperkara secara psokologis terkendala, di samping itu penguasaan bahasa daerah para hakim masih lemah sehingga sering terjadi misskomunikasi antara hakim dan pihak yang berperkara. Pada kenyataannnya para pihak yang berperkara lebih mudah dan nyaman berkomunikasi

${ }^{20}$ Wawancara Hakim Mediator Mahkamah Syar'iyah Meulaboh Tanggal 10 Oktober 2018.

21 Wawancara Hakim Mediator Mahkamah Syar'iyah Meulaboh Tanggal 10 Oktober 2018. 
menggunakan bahasa daerah (bahasa Aceh), sementara para hakim mediator sebagiannya terkendala dengan penggunaan bahasa daerah tersebut.Di samping sebab-sebab tersebut, para pihak yang berperkara juga sering melibatkan pihak ketiga dari keluarga untuk mendesak pemutusan perkara dipercepat di Mahkamah Syariah.

\section{Kegagalan Hakim Mediator dalam Penyelesaian Sengketa Perceraian}

Faktor yang berpengaruh terhadap kegagalan hakim mediator dalam penyelesian sengketa perceraian di Mahkamah Syar'iyah Pantai Barat Selatan Aceh yang disampaikan dari hasil wawancara sebagai berikut:

Bapak Hasanauddin mengatakan bahwa hakim terlalu muda juga menjadi sebab dimana pihak yang bercerai tidak yakin dengan mediasi yang dilakukan oleh seorang hakim yang muda umurnya karena para pihak yang berperkara mengatakan "sudah duluan saya berkeluarga dari pada bapak untuk apa mengajari saya dalam hal berkeluarga." Maka dalam hal menyelesaikan persoalan perceraian ini seorang hakim yang muda umurnya harus mencari trik-trik sendiri untuk proses mediasi. ${ }^{22}$

Hakim mediator Calang mengatakan bahwa hakim mediator belum sesuai dengan harapan Perma Nomor 1 Tahun 2008 disebabkan masih sedikit hakim mediator yang memiliki sertifikat. Maka untuk itu perlu adanya pelatihan dan seminar tentang penguatan hakim mediator. Terlalu jauh tempat tinggal atau jarak tempuh para pihak yang berperkara juga menyebabkan gagalnya mediasi contohnya mediasi dilakukan pada hari senin tetapi para pihak yang berperkara daaing hari selasa dengan alasan suratnya telat sampai kepada para pihak yang berperkara. $^{23}$

22 Wawancara HasanuddinHakim Mediator Mahkamah Syar'iyah Meulaboh Tanggal 20 Oktober 2018.

23 Hakim Mediator Mahkamah Syar'iyah Calang Tanggal 19 Agustusr 2018
Hakim Mediator mengatakan bahwa penggunaan bahasa daerah (bahasa Aceh) juga menjadi sebab kegagalan proses mediasi dimana para pihak yang berperkara di Mahkamah Syar'iyah Pantai Barat Selatan Aceh banyak berkomunikasi dengan bahasa daerah. Karena bagi hakim mediator yang berasal dari luar Aceh sangat susah untuk memahami sebuah persoalan yang di hadapai oleh para pihak yang berperkara karena pihak yang berperkara menjelaskan semua persoalan dalam bahasa daerah. ${ }^{24}$

Achmad Fikri Oslami mengatakan bahwa adanya pihak ketiga (orang tua dan keluarga). Dimana para pihak yang berperkara mau diselesaikan perkara mereka secara mediasi tetapi para pihak yang ketiga yang tidak mau diselesaikan perkara ini secara mediasi.. ${ }^{25}$

Kegagalan sebuah mediasi yang dilakukan dalam lingkup Mahkamah Syar'iyah Pantai Barat Selatan Aceh juga tidak terlepas dari kompetensi hakim mediator yang dibuktikan dengan jumlah hakim yang bersertfikat mediator, sementara para hakim yang lain adalah hakim majelis dan hanya menjalankan tugas tambahan sebagai mediator. Realita ini juga menjadi penyebab pendukung kegagalan mediasi, karena kemampuan mediasi yang digunakan hakim majelis yang merangkap sebagai mediator merupakan kemampuan komunikasi personal saja secara otodidak.Rangkap jabatan tersebut juga mengakibatkan tidak maksimalnya penanganan kasus-kasus yang harus diselesaikan, karena para hakim majelis tidak dapat fokus sebagai mediator.Disamping itu para pihak yang berperkara juga merasa terpaksa mengikuti proses mediasi karena prosedur saja sebelum pemutusan perkara harus melalui tahap mediasi ini, menurut persepsi mereka apabila tahap tersebut tidak ada, mereka

24 Hakim Mediator Mahkamah Syar'iyah Calang Tanggal 13 Juli 2018.

${ }^{25}$ Hasanuddin Hakim Mediator Mahkamah Syar'iyah Meulaboh Tanggal 23 Oktober 2018. 
cenderung berkeinginan langsung ke pemutusan perkara. Karena para pihak yang berperkara sudah bulat ingin diputuskan dengan segera perkara mereka.

\section{F. KESIMPULAN}

Peran yang ditampilkan Mediator Mahkamah Syar'iyah di Pantai Barat Selatan Aceh dalam menyelesaikan perceraian ada beberapa tahapan yang di antaranya: Pertama, melakukan gelar perkara dalam forum internal hakim untuk menganalisa masalah secara spesifik dan mendalam. Dari telaahan perkara ini para hakim mediator akan menemukan pemahaman yang baik terhadap duduk perkara. Di samping itu karakter masyarakat pihak yang berperkara juga umumnya keras-keras dan hal ini ditandai dengan karakter khas masyarakat wilayah pesisir secara teritorial. Kedua, melakukan inventarisasi masalah dari masing-masing kasus. Dalam tahap ini para hakim mediator melakukan pendalaman masalah secara teknis dengan melakukan dialog dengan pihak yang berperkara yang dilakukan secara terpisah, sehingga dapat diketahui penyebab-penyebab perceraian di antara pihak yang berperkara. Sedangkan yang menjadi kendala hakim mediator dalam memfasilitasi penyelesaian perselisihan perkara perceraian di Mahkamah Syar'iyah Pantai Barat Selatan Aceh dipengaruhi oleh beberapa factor, meliputi jarak tempuh para pihak yang berperkara, hakim terlalu muda, memahami dengan bahasa daerah, pengaruh pihak ketiga, skiil mediator yang terbatas, tidak ada ruang khusus mediasi, banyaknya perkara yang harus ditangani, kurangnya pemahaman para pihak yang berperkara tentang mediasi, waktu mediasi yang terbatas dan terpaksa mengikuti mediasi secara prosedural.

\section{DAFTAR PUSTAKA}

Alyasa' Abu Bakar, Antara Setia dan Durhaka Ulasan Tentang Hak dan Kewajiban Suami Istri, Banda Aceh: Badan Pemberdayaan Perempuan dan
Perlindungan Anak Provinsi Nanggroe Aceh Darussalam, 2001.

A Mukti Arto, Mencari Keadilan Kritik dan Solusi Terhadap Praktek Peradilan Perdata di Indonesia, Yogyakarta: Pustaka Pelajar, 2000.

Anselen Starauss dan Juliet Corbin, DasarDasar Penelitian Kualitatif, Jogyakarta: Pustaka Belajar, 2003.

A.Hamid Sarong, Mediasi dan Arbitrase Tantangan Kurikulum Fakultas Syari'ah dan Hukum, (Pusat Penelitian IAIN Ar Raniry Darussalam Tahun 1984/1985.

Anonimous. Buku Komentar Peraturan Mahkamah Agung RI No. 01 Tahun 2008 tentang Pelaksanaan Mediasi di Pengadilan. Dibuat atas kerjasama MARI, Japan International Cooperation Agency (JICA) dan Indonesia Institute for Conflikct Transformation (IICT), 2008.

Anggreany Arief, Mediasi Sebagai A lternatif Penyelesaian Perkara Perdata, Jurnal Ar Risalah Vol 12 No 2, 2012.

Bambang Prasetyo, Metode Penelitian Kualitatfif Teori dan Aplikasi, Jakarta: Raja Grafindo Persada, 2007.

Deddy Mulyana, Metodologi Penelitian Kualitatif Paradigma Baru Ilmu Komunikasi dan Ilmu Sosial lain nya, Bandung; Remaja Rosdakarya, 2001.

Gunawan Widjaja, Alternatif Penyelesaian Sengketa, Jakarta: Raja Grafindo, 2001.

Imam Taqiyuddin Abubakar bin Muhammad Alhusaini, kifayatul Akhyar, Surabaya: bina Iman, t.t.

Laurence Boulle, Mediation: Principle, process, pratice, Sydney: Butterworths, 1996.

Noeng, Metodologi Penelitian Kualitatif, Yoqyakarta; Bayu Indra Grafika, 1998.

Nurnaningsih Amriani, Mediasi Alternatif Penyelesaian Sengkete Perdata di 
Pengadilan, Jakarta: Raja Grafindo Persada, 2011.

Nurwidiatmo, Akibat Hukum Penggunaan Lembaga Mediasi Sebagai Alternatif Penyelesaian Sengketa di Indonesia, Suatu Analisis Normatif Legalitas, Jurnal Penelitian Hukum Vol. IV No. 2 Juli -Desember 2003

Rachmadi Usman, Pilihan Penyelesaian Sengketa diluar Pengadilan, Bandung: Citra Aditya Bakti, 2003.

Revy S.M. Korah, Mediasi Merupakan Salah Satu Alternatif Penyelesaian Masalah dalam Sengketa Perdagangan Internasional, Ejournal.unsra, Vol.XXI/No.3/April-Juni /2013

Robert A. Baruch Bush dan Joseph P.Folger, The Promise of Mediation: Transformative Approach to Conflict, USA: Willey, 2004.

Ramdani Wahyu Sururie Ijtihad, Jurnal Wacana Hukum Islam dan Kemanusiaan, Vol. 12, No. 2, Desember 2012.

Ronald S Kraybiil, Panduan Mediator Terampil Membangun Perdamaian, Terjemahan A Supratiknya, Yoqyakarta: KANISIUS, 2001.

Syahrizal Abbas, Mediasi Dalam Perspektif Hukum Syariah, Hukum Adat dan
Hukum Nasional, Jakarta: Kencana Prenada Media Group, 2008.

Suyud Margono, ADR dan Arbitrase (Proses Pelembagaan dan Aspek Hukum), Jakarta: Gralia Indonesia, 2000.

Suharsimi Arikunto, Manajemen Penelitian, cet VII, Jakarta; Rineka Cipta, 2005.

Said Faisal, Mediasi dan Perdamaian, (Mahkamah Agung Republik Indonesia)

Suyud, Margono, Pelembagaan Alternative Dispute Resolution (ADR) di Indonesia, dimuat dalam Prospek dan Pelaksanaan Arbitrase di Indonesia, Editor Hendarmin, Djarab, dkk, Citra Aditya Bakti, Bandung, 2001.

Soeharto, Mediasi dan Perdamaian, (Jakarta: Mahkamah Agung Republik Indonesia, 2005.

Undang-Undang Nomor 1 Tahun 1974 Tentang Perkawinan.

William J Goode, Sosiologi Keluarga, Cet. VII Terjemahan Lailahanoum Hasyim, Jakarta: Bumi Aksara, 2007.

Yahya Harahap, Hukum Acara Perdata tentang Gugatan, Persidangan, Penyitaan, Pembuktian dan Putusan Pengadilan, Jakarta: Sinar Grafika, 2004. 